\title{
Tanggung Jawab Notaris Terkait Penyelundupan Hukum Dalam Hal Perjanjian Nominee
}

\author{
Cokorda Istri Ratih Dwiyanti Pemayun1, I Made Sarjana²
}

${ }^{1}$ Magister (S2) Kenotariatan Universitas Udayana, E-mail: cokratih9f@gmail.com ${ }^{2}$ Fakultas Hukum Universitas Udayana, E-mail: made_sarjana@unud.ac.id

\begin{tabular}{l}
\hline Info Artikel \\
\hline Masuk : 17 Januari 2021 \\
Diterima : 21 Januari 2021 \\
Terbit : 1 April 2021 \\
Keywords : Nominee, \\
Notary, Legal Smuggling, \\
Agreement \\
\\
\\
Kata kunci: Nominee, \\
Notaris, Penyelundupan \\
Hukun, Perjanjian \\
Corresponding Author: \\
Cokorda Istri Ratih \\
Dwiyanti Pemayun, email: \\
cokratih9f@gmail.com \\
DOI: \\
10.24843/AC.2021.v06.i01.p12 \\
\end{tabular}

\section{Pendahuluan}

Manusia diketahui memiliki beragam kebutuhan yang diperlukan untuk menunjang kelangsungan hidup, salah satunya adalah kebutuhan utama yang disebut sebagai kebutuhan pokok. Terdapat beberapa macam kebutuhan manusia yang dikategorikan menjadi kebutuhan seperti primer, kebutuhan sekunder, dan kebutuhan tersier. Tanah diketahui sebagai salah satu bentuk kebutuhan pokok manusia, karena pada umumnya tanah sendiri memilki fungsi yakni untuk tempat tinggal. Tidak hanya tempat tinggal 
tanah juga memiliki fungsi sebagai suatu sarana yang dapat menghasilkan. Salah satu contohnya dengan adanya tanah seseorang dapat membangun sebuah usaha, yang dijadikan suatu lapangan pekerjaan dan kemudian menghasilan suatu pendapatan usaha guna memenuhi kebutuhan hidup.

Melihat kegunaan tanah yang begitu penting, maka hal tersebut berdampak pula terhadap negara. Saat ini perkembangan zaman yang sangat pesat, tanahlah yang menjadi suatu objek dalam upaya pengembangan sektor ekonomi di Indonesia. Pada saat pemerintahan Presiden Jokowi, beliau berupaya untuk melakukan peningkatan terhadap investasi di Indonesia dalam hal Penanaman Modal Asing (PMA), sebab investasi mampu mendorong perekonomian suatu negara sehingga nantinya dapat menstabilkan perekonomian negara. ${ }^{1}$ Warga negara asing sangat tertarik untuk mengembangkan suatu bisnis/ usaha di Indonesia, karena mereka melihat kekayaan alam Indonesia yang melimpah, investasi ini nantinya pasti akan membantu peningkatan pembangunan negara dan pendapatan negara. Perolehan tanah kemudian dilakukan oleh orang berkewarganegaraan asing dengan orang berkewarganegaraan Indonesia, untuk melakukan aktivitas menjual dan membeli tanah. ${ }^{2}$ Investor asing yang ingin berinvestasi untuk kepentingan perusahaan tentu saja membutuhkan tanah tempat untuk menetap atau tinggal untuk jangka waktu tertentu. Ketentuan izin tinggal diatur dalam UU Keimigrasian No. 6 Tahun 2011 (selanjutnya disebut Undang-Undang Keimigrasian). Selain untuk tujuan pariwisata, warga negara asing yang masuk ke Indonesia juga mencoba berinvestasi di bisnis dengan berbagai cara, salah satunya dengan penguasaan lahan.

Peran hukum disini sangatlah penting karena hukum merupakan aturan hidup yang dapat diandalkan yang menjamin kepentingan sosial. ${ }^{3}$ Indonesia memiliki hukum perjanjian, salah satu diantara beberapa asas yang menjadi dasar perjanjian yaitu asas kebebasan berkontrak. Asas kebebasan berkontrak berarti setiap orang berhak menentukan perjanjian yang diinginkan tanpa adanya faktor wajib, dan setiap kesepakatan yang dicapai menjadi hukum yang harus ditaati bagi orang yang membuat kesepakatan tersebut. Namun, asas ini sering disalah artikan dan dijadikan batu loncatan untuk memenuhi keinginan pelanggar aturan. Hal ini terlihat dari dasar kesepakatan nominee, yaitu menghindari atau mengelak dari peraturan perundangundangan Indonesia yang menjadi pembatas hak atas tanah untuk orang berkewarganegaraan asing. Adanya keterbatasan orang asing memiliki hak milik atas tanah maka WNA berusaha untuk meminjam nama pihak lain yang berkewarganegaraan Indonesia untuk mengatasnamakan sertifikat kepemilikan tanah dan mengambil semua tindakan hukum untuk menguasai tanah hak milik tersebut. Hak milik atas tanah hanya dimiliki oleh Warga Negara Indonesia. ${ }^{4}$ Hal tersebut menunjukkan bahwa kepemilikan atas tanah tidak bisa dimiliki selain warga negara Indonesia. Pasal 26 ayat (2) UUPA menyataan pengalihan kepemilikan langsung atau tidak langsung kepada orang asing tidak dibenarkan, dan tanahnya langsung dikuasai

1 Agung, I., \& Kawuryan, E. S. (2017). Implikasi Akta Niminee Sebagai Dasar Permohonan Pengampunan Pajak. Al-Daulah: Jurnal Hukum dan Perundangan Islam, 7(2), 488-510, hlm.490.

2 Jastrawan, I. D. A. D., \& Suyatna, I. N. (2019). Keabsahan Perjanjian Pinjam Nama (Nominee) oleh Warga Negara Asing dalam Penguasaan Hak Milik Atas Tanah di Indonesia. Kertha Semaya: Journal Ilmu Hukum, 7(12), 1-13.hlm.3-4.

${ }^{3}$ Ali, A. (2008). Menguak Tabir Hukum. Bogor: Ghalia Indonesia, hlm. 29.

${ }^{4}$ Supramono, G. (2014). Hukum Orang Asing di Indonesia. Jakarta: Sinar Grafika. Hlm.26. 
oleh negara. Namun, pihak asing biasanya menghindari situasi ini dengan menggunakan nominee agreement, dan selanjutnya disetujui oleh warga negara Indonesia. Perjanjian nominee dikenal sebagai bentuk penyelundupan hukum. Indonesia belum memiliki regulasi tentang nominee agreement, artinya dalam kesepakatan tersebut terdapat kekosongan norma. Ketidakpastian hukum membuat perjanjian dijadikan sebagai alat penyelundupan hukum. Kasus nyata terkait praktik kesepakatan perjanjian nominee dapat dilihat dalam Putusan Mahkamah Agung No. 193 / PDT / 2015 / PT.DPS tanggal 01/02/2016. Adanya perjanjian nominee pada akta di dalam putusan diatas yakni sewa tanah antara orang asing dan warga negara Indonesia, tanah bersertifikat atas nama pihak lain berkewarganegaraan Indonesia, tetapi penguasaan tanah adalah milik orang asing.

Perjanjian nominee, biasanya diikuti dan / atau termasuk dalam perjanjian lain, sebagai cara untuk mengontrol kepemilikan tanah orang asing. Terdapat beberapa akta notaris dalam kasus ini yaitu, Akta Sewa Menyewa Tanah No. 89 tanggal 24/03/2008, Akta Notaris Pengakuan Hutang No. 90 tanggal 24/03/2008, Akta Notaris Pernyataan Kuasa No. 91 tanggal 24/03/2008 dan Akta Notaris Pemberian Hak Tanggungan (APHT) No. 108 tanggal 01/04/2008. Perbuatan Notaris ini akan mengakibatkan kerancuan hukum dan tidak ada kepastian hukum, disebabkan oleh objek tanah yang disepakati adalah objek tanah yang sama. Jika terjadi sengketa di kemudian hari akan mengakibatkan ketimpangan hukum.

Salah satu akta yakni akta Sewa Menyewa No. 89 tanggal 24/03/2008 yang memuat sewa antara Warga Negara Indonesia dengan Orang Asing. Dari perspektif UUPA, orang berkewarganegaraan asing hanya memiliki hak guna tanah dan hak sewa. Hak sewa tanah diketahui sebagai pemberian hak kepada pihak lain memanfaatkan tanah dan berkewajiban membayar sewa pada waktu tertentu. Namun dalam akta notaris terdapat klausul yang tidak logis tentang masa sewa tanah tersebut, yakni jangka sewa 100 tahun. Meskipun waktu sewa itu ditentukan oleh kesepakatan para pihak, namun jangka waktu yang ditentukan dalam kontrak yang diaktakan tidak relevan dengan kebiasaan dan kepatutan yang berlaku di Indonesia. Akta nominee dikenal dengan tindakan penyelundupan hukum, karena di dalam kesepakatan disebutkan dana yang digunakan warga negara Indonesia untuk membeli tanah itu disediakan oleh orang asing dan kemudian diberikan oleh orang Indonesia. Warga negara Indonesia menjual atau mengalihkan hak kepada orang asing atas nama orang berkewarganegaraan Indonesia. Oleh karena itu, pengalihan kepemilikan tanah kepada orang asing otomatis masuk dalam perjanjian nominee. Sebagaimana penjabaran diatas, penulis meneliti isu dengan judul “Tanggung Jawab Notaris Terkait Penyelundupan Hukum Dalam Hal Perjanjian Nominee"

Berdasarkan permasalahan yang telah dikemukakan, dapat dirumuskan 2 (dua) masalah yang nantinya akan dibahas pada tulisan ini yaitu mengenai 1 . Bagaimana legalitas sewa-menyewa tanah oleh warga negara asing yang diikuti dengan perjanjian nominee ditinjau dari hukum positif di Indonesia? dan 2. Bagaimana tanggung jawab Notaris terkait perjanjian nominee dalam Putusan MA No. 193/PDT/2015/PT.DPS?

Penulisan ini agar menjadi berguna dikemudian hari memiliki suatu tujuan yang hendak dicapai, yaitu bertujuan untuk memahami secara umum mengenai legalitas sewa-menyewa tanah oleh warga negara asing yang diikuti dengan perjanjian nominee 
ditinjau dari hukum positif di Indonesia, dan tanggung jawab Notaris terkait perjanjian nominee dalam Putusan MA: 193/PDT/2015/PT.DPS.

Penulisan ini dibuat dengan menuangkan pemikiran-pemikiran yang baru dan orisinil guna untuk kemajuan dunia pendidikan, walaupun ditemukan tulisan yang mirip atau serupa dengan tulisan yang lain yang lebih dulu ada, namun tulisan ini tetap memiliki unsur - unsur pembaharuan didalamnya. Berikut dilampirkan 2 (dua) tulisan yang memiliki topik pembahasan yang serupa sebagai pembanding, antara lain: Jurnal yang ditulis oleh Endah Pertiwi, yang diterbitkan oleh Magister Kenotariatan Universitas Brawijaya, Vol. 1 Tahun 2019. Judul "Tanggung Jawab Notaris Akibat Pembuatan Akta Nominee Yang Mengandung Perbuatan Melawan Hukum Oleh Para Pihak." Rumusan masalah yaitu "tanggung jawab notaris terhadap perbuatan melawan hukum yang dilakukan para pihak dalam akta Nominee dan Konstruksi hukum untuk menanggulangi perbuatan melawan hukum." 5 Dan Jurnal yang ditulis oleh Yosia Hetharie, yang diterbitkan oleh Fakultas Hukum Universitas Pattimura, Vol. 25 , Januari - Juni 2019. Judul "Perjanjian Nominee sebagai Sarana Penguasaan Hak Milik atas Tanah oleh Warga Negara Asing (WNA) Menurut Kitab Undang-Undang Hukum Perdata". Keabsahan Perjanjian Nominee dan Pertanggungjawaban Notaris/PPAT Dalam Mengeluarkan Akta-Akta" ${ }^{6}$

Berdasarkan perbandingan pada jurnal atau tulisan yang terdahulu dengan tulisan ini tidak terdapat upaya untuk menjiplak tulisan sebelumnya, namun tetap tulisan ini tetap memiliki unsur pembaharuan didalamnya. Permasalahan yang dibahas didalamnya yaitu legalitas sewa-menyewa yang dilakukan orang asing serta diikuti perjanjian nominee yang meninjau dari peraturan perundang-undangan yang ada dan tanggung jawab Notaris terkait perjanjian nominee.

\section{Metode Penelitian}

Penelitian ini adalah penelitian hukum normatif. Penelitian tersebut dilakukan melalui pengkajian norma hukum itu sendiri dan mengkaji asas-asas, peraturan perundangundangan lain, pendapat ahli hukum, dan sumber hukum lainnya. Dalam metode penelitian hukum secara normatif, pertama-tama yang harus dilakukan ialah meneliti demi menemukan hukum positif atau hukum yang berlaku kini, ditambah juga dengan studi kepustakaan dari berbagai macam buku, jurnal, atau juga pernyataanpernyataan dari para ahli serta literatur-literatur yang mungkin ada dan kemudian setelah mendapatkan itu semua, maka dikaitkanlah dengan isu-isu hukum yang terjadi di masyarakat sehingga mendapatkan kesimpulan terhadap hak dan kewajiban berdasarkan hukum secara subyektif. ${ }^{7}$

Pendekatan yang digunakan adalah pendekatan konsep hukum dan pendekatan perundang-undangan. Pendekatan konsep dimaksudkan yaitu melakukan pengkajian

5 Pertiwi, E. (2018). Tanggung Jawab Notaris Akibat Pembuatan Akta Nominee Yang Mengandung Perbuatan Melawan Hukum Oleh Para Pihak. Jurnal Ius, 6(2), 246-258.

${ }^{6}$ Hetharie, Y. (2019). Perjanjian Nominee sebagai Sarana Penguasaan Hak Milik atas Tanah oleh Warga Negara Asing (WNA) Menurut Kitab Undang-Undang Hukum Perdata. SASI, 25(1), 2736.

${ }^{7}$ Rusli, H.(2006). “Metode Penelitian Hukum Normatif: Bagaimana?”.Tanggerang: Law Review Fakultas Hukum Universitas Pelita Harapan, Vol. V No. 3 Tahun 2006, hlm. 50. 
norma hukum terkait dengan konsep konsep hukum yang ada dan relevan guna menjawab permasalahan yang disediakan. Pendekatan perundang-undangan dilakukan dengan cara-cara mengkaji norma hukum tersebut menggunakan peraturan perundangundangan dan relevan, pendekatan perundang-undangan meliputi penelusuran norma hukum guna menjawab apa yang menjadi tujuan penelitian ini. Pendekatan konsep hukum digunakan untuk mengkaji permasalahan guna mencari jawaban dengan konsep-konsep hukum yang ada dan relevan, konsep dapat berupa doktrin para ahli hukum yang sudah lumrah digunakan oleh ahli ahli hukum lainya. ${ }^{8} 2$ (dua) Bahan hukum yang dipakai yakni primer dan sekunder. Bahan Hukum Primer berupa aturan hukum yang memiliki hubungan dalam pembahasan. Bahan hukum sekunder yakni jurnal dan beberapa literatur terkait yang ada hubungannya serta termutakhir guna mendukung pembahasan pada permasalahan yang ada. ${ }^{9}$

\section{Hasil dan Pembahasan}

\section{1 Legalitas Sewa-Menyewa Tanah Oleh Warga Negara Asing Yang Diikuti Dengan Perjanjian Nominee Ditinjau Dari Hukum Positif Di Indonesia}

Tujuan perjanjian nominee bertentangan dengan hukum dan peraturan saat ini. Dapat diartikan bahwa perjanjian nominee tidak memenuhi syarat keempat pada perjanjian yaitu "suatu sebab yang halal" yang merupakan faktor objektif. "Suatu sebab yang halal" merupakan unsur yang harus terpenuhi jika tidak akan bertentangan dengan Kitab Undang-Undang Hukum Perdata (KUHPer) pada pasal 1335 dan 1337. Pada pasal 1335 KUHPer menentukan "apabila suatu perjanjian dibuat karena sesuatu hal yang dilarang oleh peraturan yang berlaku maka perjanjian itu tidak memiliki kekuatan hukum." Ketentuan pasal 1337 KUHPer mengatur: "sesuatu yang terlarang adalah sesuatu yang dilarang oleh undang-undang dan bertentangan dengan nilai kesusilaan dan ketertiban umum." Dalam hal ini perjanjian nominee tidak memenuhi "suatu sebab yang halal", sehingga menyebabkan kesepakatan itu menjadi tidak sah. Perjanjian tersebut batal demi hukum, dalam artian perjanjian akan hapus atau tidak ada, dan tidak menimbulkan akibat hukum bagi pihak-pihak bersangkutan.

Perjanjian Nominee memiliki sifat yang timbal balik antar pihak dimana didalamnya terdapat pemenuhan kewajiban suatu prestasi. Perjanjian nominee ini juga bersifat lastgeving, dimana lebih menekankan suatu kewajiban pada si penerima kuasa. Pada umumnya si pemberi kuasa bersifat volmacht yaitu kewenangan dalam perjanjian diberikan kepada penerima kuasa sebagai wakil dari pemberi kuasa, sehingga sifat si pemberi kuasa ini merupakan perjanjian sepihak.

Perjanjian sewa tanah oleh orang asing yang diikuti dengan perjanjian nominee, apabila ditinjau dari Undang-Undang Pokok Agraria (UUPA) pada pasal 45, yang menjadi salah satu subyek hak sewa adalah WNA, sehingga tidak menjadi masalah jika WNA menyewa bangunan atau tanah. Tetapi sering terjadi pengalihan tanah oleh WNA dilakukan dengan tidak langsung yaitu mengambil suatu kepemilikan atas tanah. Perbuatan dilakukan dengan menggunakan nama orang berkewarganegaraan Indonesia, kemudian orang berkewarganegaraan Indonesia tersebut mengajukan surat

\footnotetext{
8 Wijaya, I. G. A. (2019). Kekuatan Hukum Covernote Notaris sebagai Produk Hukum Notaris. Acta Comitas: Jurnal Hukum Kenotariatan, 4(1), 90-98. hlm. 93

${ }^{9}$ Marzuki, P. M. (2005). Penelitian Hukum. Jakarta: Kencana Prenada Media Group.hlm.181
} 
izin memberi kuasa orang berkewarganegaraan asing untuk mewakili segala tindakan terhadap objek yang dimaksudkan yakni dalam hal ini tanah hak milik.

Peluang investasi di Indonesia sangatlah tinggi sehingga WNA banyak yang tertarik untuk berinvestasi di Indonesia, tetapi WNA memiliki hambatan terkait tempat dalam pengembangan investasinya, kemudian banyak WNA beranggapan bahwa peraturan mengenai hak atas tanah di Indonesia dapat menghambat bisnis mereka di Indonesia. Maka dari itu tidak menutup kemungkinan muncullah niat buruk orang asing terhadap penguasaan tanah dengan seolah-olah menjadi miliknya. Klausula di dalam jangka waktu yang buat oleh WNA, yaitu menggunakan durasi waktu yang sangat panjang hingga bertahun-tahun bahkan seumur hidupnya. Jelas perjanjian tersebut tidak dapat dikatakan logis karena menyewa tanah dengan durasi hingga seumur hidup bukanlah hal wajar yang dapat diterima.

Klausula seumur hidup dan/atau 100 tahun menimbulkan permasalahan karena waktu sewa tanah maupun bangunan ini tidak berlaku untuk sementara waktu. Tetapi jika kita melihat dalam undang-undang sendiri masih terdapat kekaburan norma dalam suatu pengertian kurun waktu tertentu ini, kemudian hal ini disalah gunakan oleh orangorang yang memilki kepentingan dalam perjanjian nominee. Muncullah niat WNA dalam hal menguasai objek sewa dengan waktu lama serta menimbulkan pertentangan dalam kebiasaan jangka waktu yang berlaku terhadap jangka waktu sewa yang berlangsung sementara waktu, kemudian disini langsung terlihat bahwa terjadinya pengalihan hak milik oleh WNA, diketahui dengan adanya jangka waktu yang cukup lama dengan tidak adanya jangka waktu tertentu dalam penyewaan tanah atau bangunan. Adapun konsekuensi dari adanya perjanjian nominee yaitu dilarang dalam hukum Indonesia karena telah meminjam nama warga negara Indonesia. Dengan demikian, akta perjanjian ini dapat batal demi hukum. Akta tersebut seolah warga negara Indonesia yang menjadi hak milik atas tanah. Kata memiliki bermaksud melakukan perbuatan tersebut atas nama orang asing. ${ }^{10}$

Pengalihan penguasaan tanah yang dilakukan oleh WNA dengan cara di dalam perjanjian diberi klausula yaitu jangka waktu 100 tahun dan/atau seumur hidup. Hal ini membuat suatu kerancuan perihal dengan jangka waktu dalam perjanjian, sebenarnya perjanjanjian ini dapat dicegah oleh seorang notaris, karena notaris memiliki kewenangan dalam akta dan notaris juga yang seharusnya menjadi tempat atau sarana hukum dalam hal akta tersebut. Klausula semumur hidup yang dijadikan ukuran waktu dalam perjanjian, tidak memenuhi unsur essensialia, karena waktu tertentu yaitu dimaksud waktu dengan jelas dapat ditentukan. Jadi jika unsur essensialia ini tidak dipenuhi, maka kesepakatan itu akan dibuat oleh semua pihak menjadi tidak resmi maka antar para pihak tidak terikat.

Perjanjian nominee dalam bentuk nominee langsung, maupun yang mengikuti sewamenyewa tanah oleh WNA merupakan perbuatan penyelundupan hukum. Melihat dari sisi peraturan hukum di Indonesia, yaitu sesuai dengan Pasal 1320 KUH Perdata keabsahan sewa-menyewa tanah oleh WNA yang diikuti dengan perjanjian nomiee merupakan perjanjian yang tidak sah, karena bertentangan dengan peraturan pasal 1339

10 Putra, I. W. E. A., \& Agung, I. G. N. (2009). Akibat Hukum Terhadap Kepemilikan Tanah di Bali oleh Orang Asing dengan Perjanjian Nominee. hlm. 4. 
KUH Perdata, pasal 1548 KUH Perdata kemudian bertentangan di UUPA pada pasal 9, pasal 21 dan pasal 26 ayat (2), sehingga tidak memenuhi syarat "suatu sebab yang halal".

\subsection{Tanggung Jawab Notaris Terkait Perjanjian Nominee Dalam Putusan Mahkamah Agung No. 193/PDT/2015/PT.DPS}

Perjanjian nominee terbagi menjadi 2 (dua) jenis yakni perjanjian nominee langsung dan perjanjian nominee tidak langsung. Pada penulisan ini putusan yang diangkat adalah, putusan mengenai adanya perjanjian yang mana diketahui bahwa, terdapat perjanjian dalam hal pemindahan kepemilikan tanah tidak dilakukan secara langsung kepada WNA. Putusan ini termasuk dalam bentuk perjanjian nominee tidak langsung. Ketentuan pasal $1320 \mathrm{KUH}$ Perdata tidak terpenuhi di masing-masing akta dalam putusan ini. Pendapat hakim mengenai putusan ini unsur objektif yang dimaksud adalah "suatu hal sebab yang halal", dan kemudian pasal ini akan mengarah pada pasal 1335 KUHPer dan 1337 KUHPer, kedua ketentuan pasal tersebut mengandung kekuatan mengikat tidak dimiliki melalui kesepakatan, jika kesepakatan tersebut melanggar hukum, dan jika perbuatan itu dilarang dalam undang-undang, hal ini merupakan suatu sebab disebut terlarang.

Tergambar adanya suatu praktik nominee di dalam putusan diatas, hal ini tidak terlepas dari peran notaris. Pendapat hakim dalam putusan ini adalah Notaris mempunyai wewenang untuk pembuatan akta otentik maupun akta dibawah tangan, dan jika terjadi permasalahan nantinya Notaris memilki kekuatan pembuktian yang sempurna. Jadi notaris seharusnya mampu mencegah adanya penyelundupan hukum melalui pembuatan akta perjanjian nominee.

Gambaran mengenai kasus putusan diatas yaitu adanya kerja sama antara pihak WNA dengan Notaris A. Notaris A harusnya selektif dalam pembuatan akta karena telah tertera dalam akta yang menjadi subjek disini adalah WNA. Disini Notaris harusnya sangat paham mengenai batasan kepemilikan tanah terhadap WNA di Indonesia, karena dalam undang-undang sendiri yaitu dilihat dari UUPA, kepemilikan hak milik atas tanah dilarang bagi WNA. WNA disini hanya memperoleh hak sewa dan hak pakai berupa bangunan, sehingga bagi WNA maupun WNI yang menjadi pihak dalam perjanjian tersebut akan merasa dirugikan, dikarenakan perjanjian tersebut menjadi batal sehingga para pihak tersebut akan dihilangkan dari hak dan kewajibannya dalam perjanjian.

Beberapa kasus yang melibatkan Notaris dalam dugaan keterlibatannya dalam Akta Nominee. Adanya hubungan dengan prinsip keadilan dalam praktik nominee yang menjadi suatu nilai tertentu digunakan untuk melihat kepentingan semua pihak. Posisi notaris disini terlibat didalam akta karena sebagai yang membuat akta, apabila perjanjian nominee tetap dibuatkan maka akan menimbulkan suatu kerugian di masingmasing pihak. Dengan begitu lahirlah suatu tanggung jawab notaris dalam aktanya yang batal demi hukum, yaitu mengunakan 2 macam teori pertanggungjawaban yaitu pertanggungjawaban liability dan pertanggungjawaban responsibility. Liability merupakan suatu tanggung gugat dimana tergantung pada suatu karakter hak dan kewajiban dan hal ini dapat mengakibatkan adanya kerugian, kejahatan, biaya, atau kondisi yang berlawanan dengan undang-undang. Penerapan liability dalam putusan ini 
terlihat saat hakim memutuskan untuk mengganti kerugian pada pihak yang dirugikan. Responsibility yaitu tanggung jawab berdasarkan adanya suatu kewajiban yang dapat termasuk dalam hal ini termasuk putusan serta kemampuan yang mana kemampuan ini merupakan suatu kewajiban yang memilki tanggung jawab atas undang-undang. Penerapan responsibility terlihat, yaitu tanggung jawab seorang Notaris dalam pembuatan aktanya mengenai perjanjian nominee. ${ }^{11}$

Secara umum, apabila Notaris membuatkan Akta Nominee dimana nantinya terdapat unsur perbuatan yang melawan hukum, akan berakibat akta menjadi batal demi hukum. Karena sebagai Notaris wajib mengetahui larangan mengenai perjanjian tersebut karena dapat merugikan para pihak atau notaris sendiri. Perbuatan melawan hukum bukan dimaksudkan sebagai pelanggaran hukum saja, tetapi juga dimaksudkan untuk melanggar tata krama, prinsip kehati-hatian, dan dan kesusilaan diantara hubungan sesama warga masyarakat. ${ }^{12}$

Pelaksanaan dari kesepakatan tersebut tidak lepas dari notaris yang kurang hati-hati. Menurut UUJN pasal 15 ayat (2) mengenai kewenangan Notaris. Notaris seharusnya lebih seksama dalam memeriksa dan menilai suatu akta, agar mengetahui ketidaksesuaian dan pelanggaran peraturan perundang-undangan yang berlaku, sehingga tidak mengurangi kewenangan untuk mengeluarkan akta, dan tidak menjadi sarana penyelundupan hukum.

Adapun macam-macam tanggung jawab yang dimiliki oleh seorang notaris, ada 3 (tiga) yaitu perdata, pidana dan administrasi. Dari segi perdata, Notaris dapat bertanggungjawab dengan cara mengganti kerugian akibat perbuatannya melawan hukum, ganti rugi ini dapat berupa uang. Selain uang yang ditentukan oleh penggugat dan dianggap pantas oleh hakim, kompensasi dalam bentuk lain juga dapat diberikan. Mengenai bentuk kompensasi lain selain uang, melihat dari pernyataan Hoge Raad, bahwa persamaan tersebut "Pelaku perbuatan melanggar hukum dapat dihukum untuk membayar sejumlah uang selaku pengganti kerugian yang ditimbulkannya kepada pihak yang dirugikannya, tetapi kalau pihak yang dirugikan menuntut ganti rugi dalam bentuk lain dan hakim menganggap sebagai bentuk ganti rugi yang sesuai, maka pelaku tersebut dapat dihukum untuk melakukan prestasi yang lain demi kepentingan pihak yang dirugikan yang cocok untuk menghapus kerugian yang diderita" ${ }^{13}$ Di sisi pidana, notaris wajib bertanggung jawab atas klausul penipuan dan pemalsuan dalam KUHP terhadap perbuatan notaris. Secara administratif dianggap tidak sah bagi seorang notaris untuk membuat akta nominee, sehingga notaris akan dikenakan sanksi yaitu pemberhentian secara tidak hormat.

\footnotetext{
${ }^{11}$ Hetharie, Y. (2019). Perjanjian Niminee sebagai Sarana Penguasaan Hak Milik atas Tanah oleh Warga Negara Asing (WNA) Menurut Kitab Undang-Undang Hukum Perdata. SASI, 25(1), 2736. hlm. 35.

12 Prayogo, S. (2016). Penerapan Batas-Batas Wanprestasi dan Perbuatan Melawan Hukum dalam Perjanjian. Jurnal Pembaharuan Hukum, 3(2), 280-287. hlm.284.

${ }^{13}$ Azhari, M. E. (2018), “Tanggung Jawab Notaris Dalam Pembuatan Akta Perjanjian Nominee Dalam Kaitannya Dengan Kepemilikan Tanah Oleh Warga Negara Asing Di Lombok", Jurnal Akta, Mahasiswa Program Magister (S2) Kenotariatan Fakultas Hukum UNISSULA, Vol. 5 No. 1 Maret 2018, hlm. 46.
} 
Putusan MA: 193 / PDT / 2015 / PT.DPS, ada beberapa akta tidak sesuai terhadap aturan yang berlaku yaitu UUPA Pasal 9, UUPA Pasal 21, UUPA Pasal 26 ayat(2), dan Pasal 1320 KUHPer. Jika melihat Pasal 1335 KUHPer, disebutkan "jika kesepakatan yang dicapai melanggar ketentuan perundang-undangan, maka kesepakatan tersebut tidak mengikat," sehingga akta dalam putusan diatas menjadi hapus atau dianggap tidak ada. Notaris A dan WNA tersebut memenuhi ketentuan Pasal 1365 KUH Perdata, sehingga menyatakan bahwa notaris A dan orang asing tersebut melanggar hukum dan mendapat mengganti kerugian, yaitu membayar biaya atau pengeluaran yang timbul dalam perkara ini.

Pengaturan terkait sewa menyewa terdapat pada ketentuan UUPA dan Pasal 1548 KUHPer masih rancu dalam menentukan masa sewa, yaitu pihak asing menggunakan masa sewa yang panjang dengan maksud agar seolah hanya sebatas sewa menyewa biasa dan bukan merupakan pelanggaran hukum. Dengan demikian, perlu dilakukan pengaturan yang tegas mengenai masa sewa sebagai langkah preventif, untuk mengurangi berkembangnya perjanjian nominee yang dikenal dengan istilah penyelundupan hukum.

\section{Kesimpulan}

Legalitas sewa-menyewa tanah hak milik yang dilakukan oleh orang berkewarganegaraan asing dan mengikuti kesepakatan dalam perjanjian nominee dengan tujuan melakukan penyelundupan hukum dengan mengatur jangka waktu sewa-menyewa tidak sesuai dengan kebiasaan dan juga peraturan yang berlaku sehingga melanggar pasal 1339 KUHPer dan pasal 1548 KUHPer. Jadi legalitas sewamenyewa tanah oleh WNA yang diikuti dengan perjanjian nominee dan dilakukan dengan tujuan untuk mengalihkan kepemilikan hak atas tanah tersebut, merupakan perjanjian yang tidak legal dan/atau tidak sah karena tidak sesuai dengan Pasal 1320 KUHPer yang berarti keabsahan perjanjian belum terealisasi. Tanggung jawab Notaris terkait perjanjian nominee dalam Putusan MA No. 193/PDT/2015/PT.DPS yaitu dikenakan sanksi perdata yaitu mengganti kerugian dengan cara menanggung biaya perkara, sehingga akibat hukum terhadap akta tersebut adalah batal demi hukum, karena setiap akta dalam Putusan MA: 193/ PDT/ 2015/ PT.DPS bertentangan dengan Pasal 9 UUPA, Pasal 21 UUPA dan Pasal 26 ayat (2) UUPA. Oleh karena itu, ketidaksesuaian dengan unsur Pasal 1320 KUHPer yaitu syarat "suatu sebab yang halal". Menurut Pasal 1335 KUHPer, jika kesepakatan yang dicapai melanggar peraturan perundang-undangan, maka kesepakatan tersebut tidak mengikat. WNA dan Notaris dinyatakan melakukan perbuatan melanggar hukum karena memenuhi semua unsur dari pasal 1365 KUH Perdata.

\section{Daftar Pustaka}

\section{$\underline{\text { Buku }}$}

Ali, A. (2008). Menguak Tabir Hukum. Bogor: Ghalia Indonesia.

Marzuki, P. M. (2005). Penelitian Hukum. Jakarta: Kencana Prenada Media Group.

Supramono, G. (2014). Hukum Orang Asing di Indonesia. Jakarta: Sinar Grafika. 


\section{Jurnal Ilmiah}

Agung, I., \& Kawuryan, E. S. (2017). Implikasi Akta Nominee Sebagai Dasar Permohonan Pengampunan Pajak. Al-Daulah: Jurnal Hukum dan Perundangan Islam, 7(2), 488-510.

Azhari, M. E. (2018), “Tanggung Jawab Notaris Dalam Pembuatan Akta Perjanjian Nominee Dalam Kaitannya Dengan Kepemilikan Tanah Oleh Warga Negara Asing Di Lombok", Jurnal Akta, Mahasiswa Program Magister (S2) Kenotariatan Fakultas Hukum UNISSULA, Vol. 5 No. 1 Maret 2018.

Hetharie, Y. (2019). Perjanjian Niminee sebagai Sarana Penguasaan Hak Milik atas Tanah oleh Warga Negara Asing (WNA) Menurut Kitab Undang-Undang Hukum Perdata. SASI, 25(1), 27-36.

Jastrawan, I. D. A. D., \& Suyatna, I. N. (2019). Keabsahan Perjanjian Pinjam Nama (Nominee) oleh Warga Negara Asing dalam Penguasaan Hak Milik Atas Tanah di Indonesia. Kertha Semaya: Journal Ilmu Hukum, 7(12).

Putra, I. W. E. A., \& Agung, I. G. N. (2009). Akibat Hukum Terhadap Kepemilikan Tanah di Bali oleh Orang Asing dengan Perjanjian Nominee.

Prayogo, S. (2016). Penerapan Batas-Batas Wanprestasi dan Perbuatan Melawan Hukum dalam Perjanjian. Jurnal Pembaharuan Hukum, 3(2), 280-287.

Rusli, H. (2006). Metode Penelitian Hukum Normatif: Bagaimana?.Tanggerang: Law Review Fakultas Hukum Universitas Pelita Harapan, Vol. V No. 3 Tahun 2006.

Wijaya, I. G. A. (2019). Kekuatan Hukum Covernote Notaris sebagai Produk Hukum Notaris. Acta Comitas: Jurnal Hukum Kenotariatan, 4(1).

\section{Peraturan Perundang-undangan}

Kitab Undang -Undang Hukum Perdata (KUH Perdata)

Undang-Undang No. 5 Tahun 1960 Tentang Peraturan Dasar Pokok-Pokok Agraria

Undang-Undang Republik Indonesia Nomor 2 Tahun 2014 Tentang Perubahan Atas Undang-Undang Nomor 30 Tahun 2004 Tentang Jabatan Notaris (Lembaran Negara Republik Indonesia Tahun 2014 Nomor 3 Dan Tambahan Lembaran Negara Republik Indonesia Nomor 5491

Putusan Mahkamah Agung Nomor: 193/PDT/2015/PT.DPS 